\title{
International finance: Meeting the needs of people in developing countries
}

\author{
Working Paper No. 16
}

José Guilherme Almeida dos Reis

Policy Integration Department

World Commission on the Social Dimension on Globalization

International Labour Office

Geneva

May 2004 
Copyright (C) International Labour Organization 2004

Publications of the International Labour Office enjoy copyright under Protocol 2 of the Universal Copyright Convention. Nevertheless, short excerpts from them may be reproduced without authorization, on condition that the source is indicated. For rights of reproduction or translation, application should be made to the Publications Bureau (Rights and Permissions), International Labour Office, CH-1211 Geneva 22, Switzerland. The International Labour Office welcomes such applications.

Libraries, institutions and other users registered in the United Kingdom with the Copyright Licensing Agency, 90 Tottenham Court Road, London W1T 4LP [Fax: (+44) (0)20 7631 5500; email: cla@cla.co.uk], in the United States with the Copyright Clearance Center, 222 Rosewood Drive, Danvers, MA 01923 [Fax: (+1) (978) 750 4470; email: info@copyright.com] or in other countries with associated Reproduction Rights Organizations, may make photocopies in accordance with the licences issued to them for this purpose.

ISBN 92-2-115718-0 (printed version)
ISBN 92-2-115723-7 (web version)

First published 2004

The designations employed in ILO publications, which are in conformity with United Nations practice, and the presentation of material therein do not imply the expression of any opinion whatsoever on the part of the International Labour Office concerning the legal status of any country, area or territory or of its authorities, or concerning the delimitation of its frontiers.

The responsibility for opinions expressed in signed articles, studies and other contributions rests solely with their authors, and publication does not constitute an endorsement by the International Labour Office of the opinions expressed in them.

Reference to names of firms and commercial products and processes does not imply their endorsement by the International Labour Office, and any failure to mention a particular firm, commercial product or process is not a sign of disapproval.

ILO publications can be obtained through major booksellers or ILO local offices in many countries, or direct from ILO Publications, International Labour Office, $\mathrm{CH}-1211$ Geneva 22, Switzerland. Catalogues or lists of new publications are available free of charge from the above address, or by email: pubvente@ilo.org

Visit our website: www.ilo.org/publns

Printed by the International Labour Office, Geneva, Switzerland 


\section{International finance: Meeting the needs of people in developing countries}

\section{Contents}

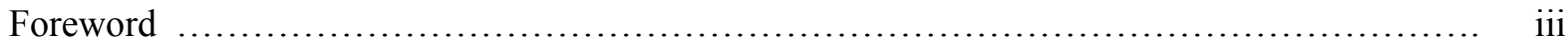

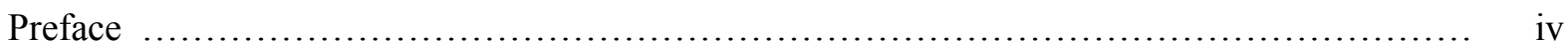

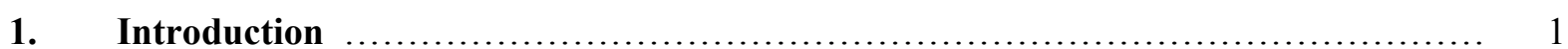

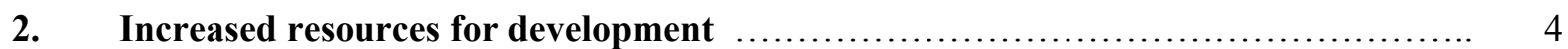

$2.1 \quad$ Official Development Assistance (ODA) $\ldots \ldots \ldots \ldots \ldots \ldots \ldots \ldots \ldots \ldots \ldots \ldots \ldots . \ldots \ldots$

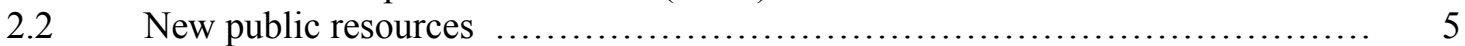

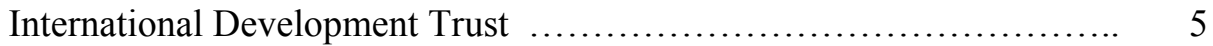

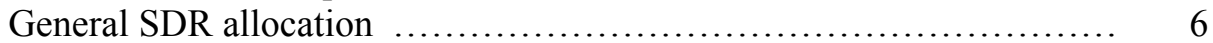

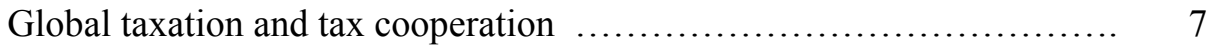

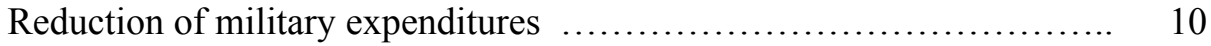

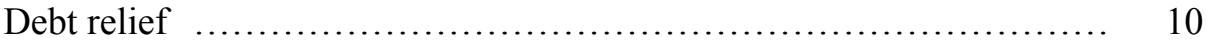

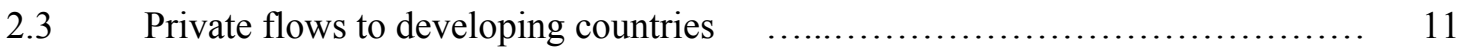

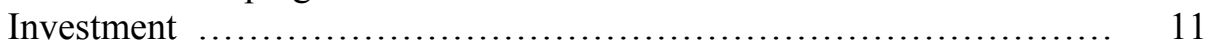

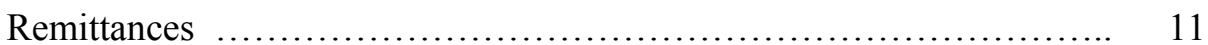

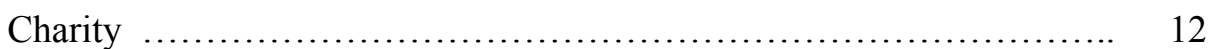

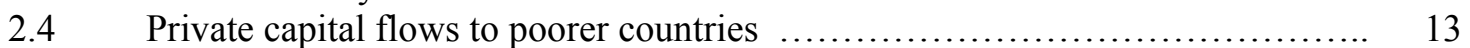

Comparative returns from investing in developing countries ........... 14

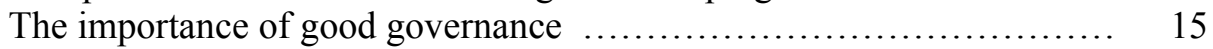

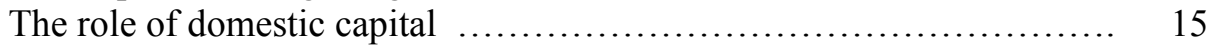

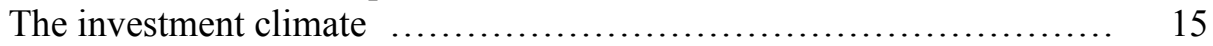

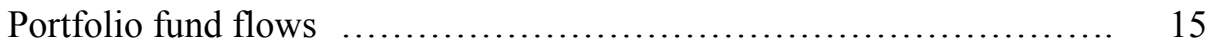

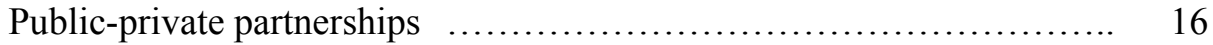

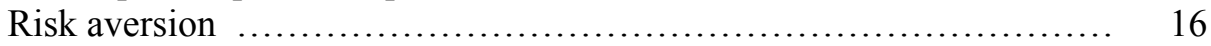

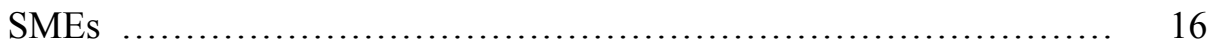

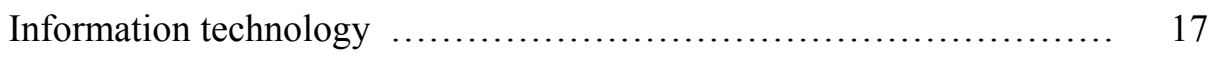

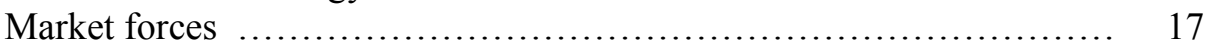

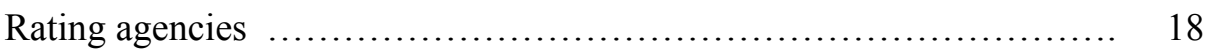

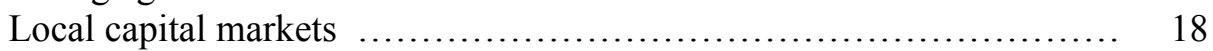

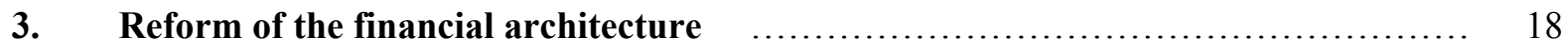

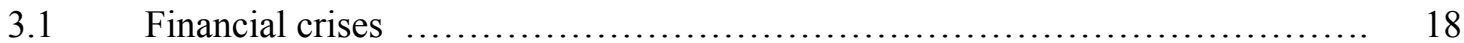

3.2 The effects of financial crises on employment $\ldots \ldots \ldots \ldots \ldots \ldots \ldots \ldots \ldots \ldots \ldots \ldots . \ldots \ldots$

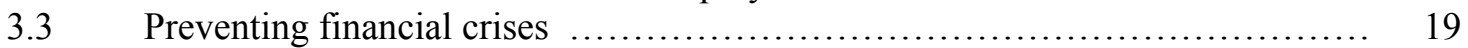

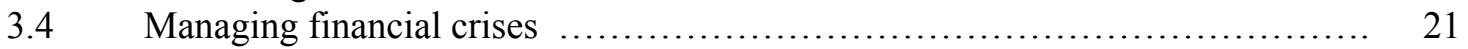

Orderly debt workout procedures $\ldots \ldots \ldots \ldots \ldots \ldots \ldots \ldots \ldots \ldots \ldots \ldots \ldots, 21$

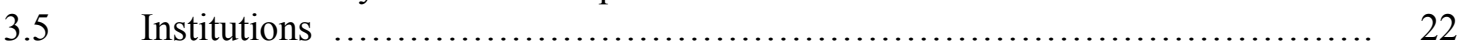

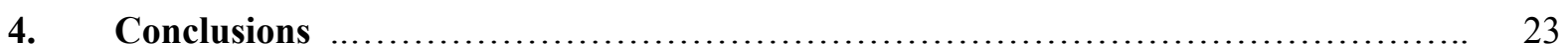

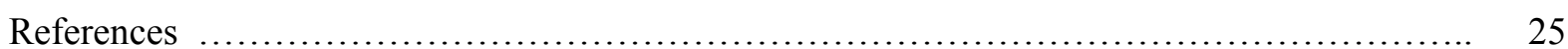




\title{
Foreword
}

In February 2002, the ILO established an independent World Commission on the Social Dimension of Globalization, co-chaired by President Tarja Halonen of Finland and President Benjamin Mkapa of Tanzania and comprising 26 eminent commissioners from a wide range of walks of life and different parts of the world, each serving in their individual capacity. Its broad goals were: to identify policies for globalization that reduce poverty, foster growth and development in open economies, and widen opportunities for decent work; to explore ways to make globalization inclusive, so that the process can be seen to be fair for all, both between and within countries; to promote a more focused international dialogue on the social dimension of globalization; to build consensus among key actors and stakeholders on appropriate policy responses; and to assist the international community forge greater policy coherence in order to advance both economic and social goals in the global economy.

The report of the World Commission, A fair globalization: Creating opportunities for all, was released on 24 February 2004. It is available on the Commission's website www.ilo.org/public/english/wcsdg/index.htm.

A secretariat was established by the ILO to support the Commission. Among other tasks, it compiled information and commissioned papers on different aspects of the social dimension of globalization. The aim was to provide the Commission with documentation and data on a wide range of options and opinions concerning subjects within its mandate, without committing the Commission or individual Commissioners to any particular position on the issues or policies concerned.

Material from this background work is being made available as working papers, as national and regional reports on meetings and dialogues, and in other forms. Responsibility for the content of these papers and publications rests fully with their authors and their publication does not constitute an endorsement by the World Commission or the ILO of the opinions expressed in them.

\author{
Gerry Rodgers \\ Director \\ Policy Integration Department
}




\title{
Preface
}

The Technical Secretariat to support the World Commission on the Social Dimension of Globalization first prepared a synthesis of ILO activities on the Social Dimension of Globalization (published as Working Paper No. 1 in this series). Documentation on the work and outcomes of other major commissions, an ideas bank, a database and knowledge networks of experts and social actors were subsequently developed. These networks have dealt with several topics, including: inclusion at the national level for the benefits of globalization to reach more people; local markets and policies; cross-border networks of production to promote decent work, growth and development; international migration as part of the Global Policy Agenda; international governance (including trade and finance); the relationship between culture and globalization; and values and goals in globalization. Gender and employment aspects were addressed throughout this work. The Reports on the Secretariat's Knowledge Network Meetings are available on the Commission's web site or in a special publication from the ILO (ISBN 92-2-115711-1).

During the course of these activities, a number of substantive background papers were prepared, which are now made available for wider circulation in the Policy Integration Department's Working Paper series (Nos. 16 to 38), as well as on the Commission's website.

The present paper was prepared by José Guilherme Almeida dos Reis, of the Instituto de Estudos do Trabalho e da Sociedade (IETS), Rio de Janeiro, Brazil. At the time of writing, Mr. Reis was a member of the technical secretariat and in his paper he presents the main convergences arising from the various views and opinions under discussion.

Mr. Reis underscores that International Finance is an important vehicle for growth, for creating jobs, for reducing poverty and for financing social services, but that flows of finance, however, are very unevenly distributed. Poor countries remain heavily dependent on public finance. Private finance for development is concentrated mainly in a small number of countries. Flows other than foreign direct investment (FDI) are very volatile and their sudden withdrawal can result in recession, unemployment and social deprivation. The paper makes therefore several policy proposals to: increase resources for development, stimulate private flows to developing countries and to reform the international financial system, in order for it to meet the needs of people.

\author{
Rolph van der Hoeven \\ Manager, Technical Secretariat \\ World Commission on the Social Dimension of Globalization
}

May 2004 



\section{International finance: Meeting the needs of people in developing countries}

\section{Introduction}

No area has been as affected by the recent wave of globalization as international finance. Cross-border investments have grown very rapidly. Annual flows of foreign direct investment soared from US\$ 57 billion in 1982 to US\$ 1,271 billion in 2000 . Private capital flows to emerging markets rose steadily until the Asian Crisis in 1997/98, reaching a peak of US\$ 228 billion in 1996. Throughout this recent period, trade has grown more rapidly than world output. There is no dispute, however, that the internationalization of financial transactions has been the main characteristic of the global economy.

The increasing interconnectivity of world financial markets was driven in part by deregulation, but progress in information technology has had a strong impact, boosting the increase in capital flows. Financial markets are already global and, given the fall in transaction costs due to technological improvements, capital will continue to move in and out of countries.

This trend has several potentially positive impacts. The reallocation of global investment funds to uses with the highest returns in the global economy leads to the maximization of world output and productivity, and will eventually contribute to a narrowing of the income gap between rich and poor countries. This is the prediction of the neoclassical growth model for the world economy, with countries tending to use similar production functions, and capital flowing from capital-abundant to capital-scarce economies. Besides receiving direct investments from abroad, developing countries can hope to benefit from inflows of portfolio capital from world capital markets. Without these flows, governments and the local private sector would not be able to reduce their cost of capital by tapping private foreign savings.

However, as recent developments clearly show, exposure to international capital markets can carry considerable risk. For developing countries, the infusion of capital in good years was substantial and helped many achieve important macroeconomic goals, such as the control of inflation; but the boom years gave way to bust, and were marked by currency or banking crises, or both.

Flows to developing countries other than FDI declined from a peak of roughly US\$ 114 billion in 1996 to a negative US\$ 147 billion in 2001. The reversal of external capital flows led to severe macroeconomic imbalances in many developing countries. This sudden change of direction often required a drastic adjustment in the balance of payments, leading to inflationary pressures and the consequent tightening of monetary and fiscal policies, with severe implications in terms of output and employment. As the 2003 Human Development Report pointed out, in consequence growth and, more importantly, human development are proceeding too slowly. 
Table 1. Number of countries presenting a decline in the Human Development Index 1975, 1980, 1985, 1990, 1995 and 2001

\begin{tabular}{|l|l|l|l|l|}
\hline \multicolumn{1}{|c|}{ Total } & \multicolumn{1}{|c|}{$\begin{array}{c}\text { High human } \\
\text { development }\end{array}$} & \multicolumn{1}{|c|}{$\begin{array}{c}\text { Medium human } \\
\text { development }\end{array}$} & $\begin{array}{l}\text { Low Human } \\
\text { development }\end{array}$ \\
\hline $\begin{array}{l}\text { Number of } \\
\text { countries with at } \\
\text { least one } \\
\text { reduction in the } \\
\text { HDI after } 85\end{array}$ & 23 out of 112 & 3 out of 41 & 8 out of 48 & 12 out of 23 \\
\hline $\begin{array}{l}\text { Number of } \\
\text { countries with at } \\
\text { least one } \\
\text { reduction in the } \\
\text { HDI before } 85\end{array}$ & 4 out of 112 & 0 out of 41 & 2 out of 48 & 2 out of 23 \\
\hline $\begin{array}{l}\text { Number of } \\
\text { countries with } \\
\text { more than one } \\
\text { reduction in the } \\
\text { HDI after } 85\end{array}$ & 12 out of 112 & 1 out of 41 & 5 out of 48 & 6 out of 23 \\
\hline $\begin{array}{l}\text { Number of } \\
\text { countries with } \\
\text { more than one } \\
\text { reduction in the } \\
\text { HDI before } 85\end{array}$ & 0 out of 112 & 0 out of 41 & 0 out of 48 & 0 out of 23 \\
\hline
\end{tabular}

Source: UNDP, 2003

Though middle income developing countries suffer from the volatility of capital flows, the least developed countries are even more affected by their absence. The late 1990s saw a surge in private capital flows to developing countries. However, these did not reach the least developed countries, and to make matters worse, they played a part in displacing official aid which was reduced.

The change in composition between private and public sources of capital flow also has been accompanied by a change in its distribution among developing countries. FDI flows to developing countries are highly concentrated, with $75 \%$ of annual flows going to only ten countries. Official aid, on the other hand, tends to flow to poorer countries. When official aid declined in relative and absolute terms, the predicted convergence of per capita incomes between emerging and industrial economies, based on trade expansion and the transfer of capital and technology from the latter to the former, did not take place and income inequality was not reduced.

There is no strong evidence to show that developing countries as a whole benefited from financial globalization. The 1990s were a cycle, not a new trend, and by the end of the decade the differences in per capita income were actually higher than before. 
Table 2. Net Capital Flows to Emerging Market Economies 1995-2002 (Billions of US dollars)

\begin{tabular}{|l|c|c|c|c|c|c|c|c|}
\hline & $\mathbf{1 9 9 5}$ & $\mathbf{1 9 9 6}$ & $\mathbf{1 9 9 7}$ & $\mathbf{1 9 9 8}$ & $\mathbf{1 9 9 9}$ & $\mathbf{2 0 0 0}$ & $\mathbf{2 0 0 1}$ & $\mathbf{2 0 0 2}$ \\
\hline $\begin{array}{l}\text { Private } \\
\text { direct } \\
\text { investment }\end{array}$ & 95 & 109.5 & 136 & 148.8 & 156.8 & 149 & 170.5 & 139.2 \\
\hline $\begin{array}{l}\text { Private } \\
\text { portfolio } \\
\text { investment }\end{array}$ & 48.8 & 94.6 & 48.5 & 1.7 & 41.4 & 12.1 & -38.5 & -36.6 \\
\hline $\begin{array}{l}\text { Other private } \\
\text { capital flows }\end{array}$ & 64.6 & 24.2 & -108.8 & -97.1 & -102.2 & -110.1 & -93.2 & -16.7 \\
\hline Total & 208.4 & 228.3 & 75.7 & 53.4 & 96.0 & 51.1 & 38.8 & 85.9 \\
\hline
\end{tabular}

Source: International Monetary Fund, World Economic Outlook, 2003

Emerging markets include developing countries, countries in transition, Korea, Singapore, Taiwan and Israel.

\section{Chart 1}

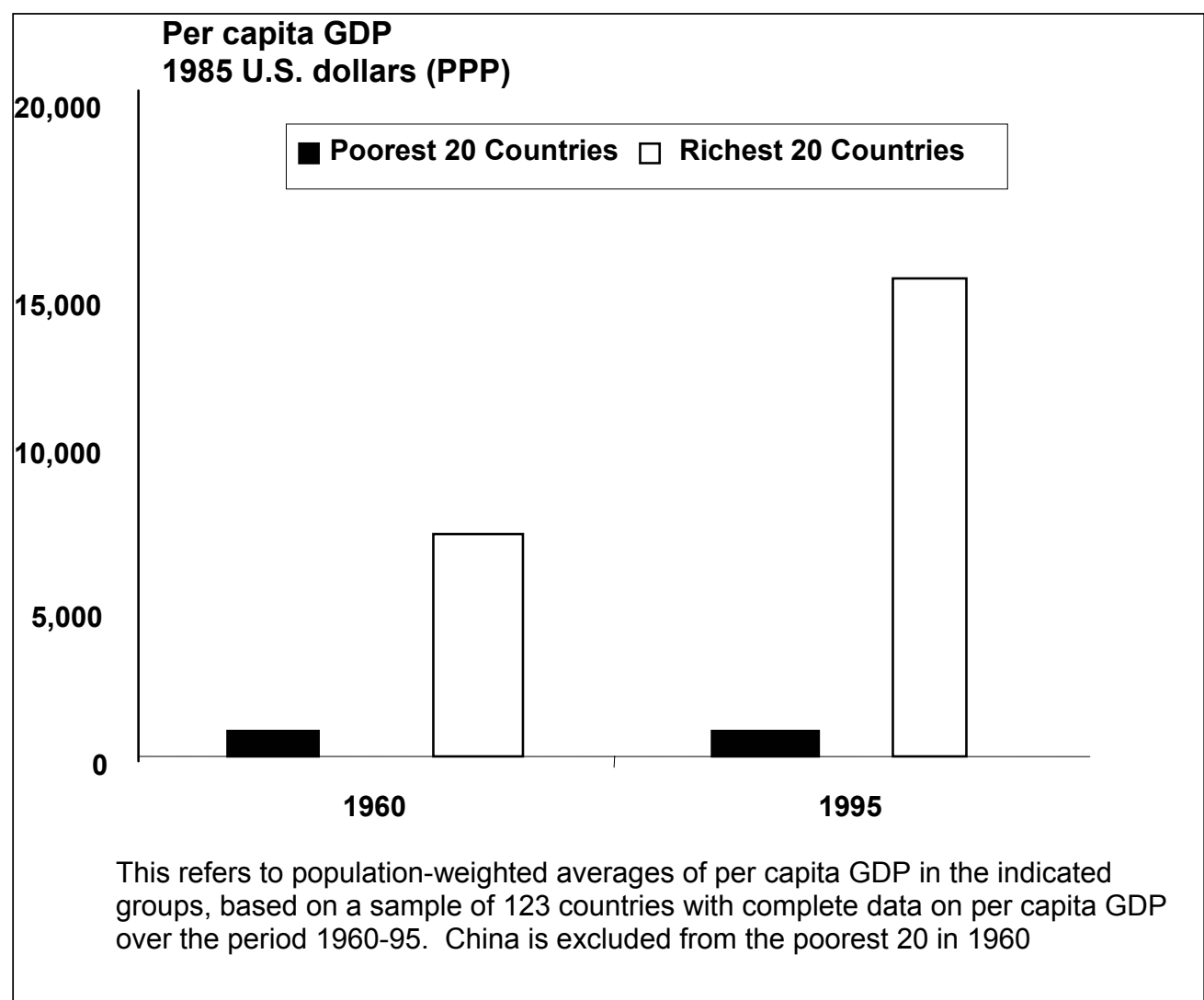

Source: $\quad$ World Bank: World Development Report 2001

Action is necessary to make resources available to the poor and to reduce international financial volatility. Rethinking old instruments and creating new ones is essential to dealing with these two intertwined phenomena. 
The set of proposals below addresses two areas: resources for development and reform of the international financial architecture. There is, of course, interaction between the two. Markets which function more efficiently may have a positive impact on the availability of resources for development. However, the approach taken here explicitly considers the need for additional resources, even in the presence of a reformed financial architecture.

\section{Increased resources for development}

\subsection{Official Development Assistance (ODA)}

In recent years, net Official Development Assistance (ODA) flows have been decreasing. In nominal terms, from 1998 on, annual figures for ODA have been around US\$ 50 billion, compared to a peak of US\$ 61 billion in 1995 and to very similar numbers at the beginning of the1990s.

The World Bank estimates that an additional US\$ 30 to 70 billion a year will be required to achieve the Millennium Development Goals by 2015. The Zedillo Report for the United Nations concluded that achieving the 2015 development targets "may require an extra \$50 billion a year"1. Donors made commitments at Monterrey to increase ODA by approximately US $\$ 12$ billion over the next three years. However, that still leaves three quarters of the total to be found. With few exceptions, national ODA levels remain far below the United Nations target of giving aid equal to $0.7 \%$ of GNP. If the developed countries delivered ODA equal to $0.7 \%$ of their GNP, as agreed, it is estimated that aid would increase by about $\$ 100$ billion a year.

A firm commitment to the $0.7 \%$ of GNP target is essential in a world founded on the principle of international solidarity. However, as several recent studies have pointed out, potential gains can be made through the reallocation of aid by shifting away from middleincome countries towards low-income countries where poverty is concentrated and which have not benefited from the increased flow of private capital.

ODA flows have been accompanied by increased conditionality and auditing requirements which enable providers to promote economic and social policies that may not be consistent with national priorities. A degree of conditionality is inevitable, and there is an urgent need in many recipient countries for improved governance. However the multiplicity of conditionality poses a problem for recipient governments since some have limited capacity to deal appropriately with these demands. Global revenue generation should be premised on shared global responsibilities for development.

Making assistance as productive as possible has been a major concern of donors, recipient countries and multilateral institutions. Waste in ODA due to transaction costs is significant and ought to be minimized. Increased cooperation among donors, harmonization of ODA procedures and the establishment of institutional frameworks at the regional level to promote mutual accountability (for both donors and recipients) are recent initiatives which are welcome and should be reinforced.

\footnotetext{
${ }^{1}$ See UN (2001).
} 
Efforts to increase and better target ODA do not exclude the imperative for developing countries themselves to commit to a substantive mobilization of domestic resources for development. This effort should encompass both the private and the public sectors and be aimed at creating an enabling environment for investment. National policies required to create this include strengthening infrastructure, education and training policies. In particular, public policies should accelerate investments which promote development goals.

Increasing financial flows to developing countries is not sufficient to support growth and poverty reduction if the receiving countries do not have enough institutional and governance capability to use these resources efficiently. For a given amount of financial flows, growth and poverty reduction increase with the quality of institutions and with access to international markets. In several cases where government is highly corrupt, resources have in fact been wasted or used for military purposes.

\subsection{New public resources}

There are various ways in which additional resources can be provided for social and economic development. The gap between current levels of ODA and the amounts required to meet the Millennium Development Goals is a spur for looking at innovative sources of development funding. Though the funds involved need not always pass through the budgets of governments or official-multilateral bodies, extra finance in the hands of public authorities is necessary if the Millennium Goals are to be reached by 2015 .

The analysis of each proposal must address several points: Does the proposal secure additional resources? Does it "crowd out" existing sources? An important issue stressed by Atkinson, ${ }^{2}$ is the degree of coordination required among countries and multilateral institutions: How demanding is each proposal in terms of new institutional arrangements? This can be decisive in terms of the political economy involved in the debate.

\section{International Development Trust Fund}

This concept, developed by the United Kingdom, envisages a financing mechanism or "facility" that would generate the funds needed to meet the Millennium Development Goals. Donors would make a series of long-term pledges for a flow of annual payments to an International Finance Facility (IFF). Each pledge would be a binding commitment, subject to high-level financing conditionality. Based on these pledges the IFF would issue bonds in its own name. It would thus turn the long-term income stream from donors into capital available for more immediate disbursement. The proposal seeks to raise the amount of development aid from just over US $\$ 50$ billion a year today to US\$ 100 billion a year up to 2015 .

There are two key advantages to this promising and forward-looking proposal. The first is the IFF's revenue-raising potential, which is based on a tried and tested principle for raising finance in international capital markets ${ }^{3}$. The second is the substantial increase in predictable and stable aid it envisages. This would minimize the negative effects associated with other aid flows, which are unpredictable and volatile.

\footnotetext{
${ }^{2}$ See Atkinson (2003), pages

${ }^{3}$ Mavrotas (2003)
} 
In the current version of the proposal, the IFF will not disburse funds directly to recipient countries. On the basis of its Overarching Principles it will instead provide funds for disbursement by existing bilateral and multilateral aid delivery channels, which may include the World Bank, the Global Health Fund, and specific government agencies of a donor country. These aid delivery channels would manage the disbursements in line with the allocation of funds agreed by the Facility.

However, there are potential shortcomings to the proposal. These include its underlying assumptions about continuous commitment on behalf of the donor community towards the implementation of the IFF during its 30 year-lifespan. This implies that the present generation will be committing future taxpayers' money. However, a large part of future incomes are already committed due to aging populations, and the ability to make financial commitments for future governments and legislatures is doubtful in certain countries like the USA.

Another difficulty is the IFF's heavy reliance on political co-ordination among participating donor countries. The IFF entails the creation of a very powerful agency, but it is difficult to imagine widespread agreement among donor countries regarding the Overarching Principles. Instead, donor countries might adopt their own conditions, which could make disbursements less predictable and stable and thus affect the achievement of Millennium Development Goals. It is therefore important to link the whole effort to recent initiatives on the aid harmonization front.

Finally, mechanisms to ensure that the Fund will provide additional funds for development are required. The fundamental question remains how much net additional resources will be generated by the certainty of underwritten flows as opposed to annual allocations by donor governments.

\section{General SDR allocation}

In recent years, as the IMF has considered proposals for resuming allocations of Special Drawing Rights (SDR) for specific purposes, and the idea of Special Drawing Rights for development has gained prominence.

The basic proposal is that the already approved Fourth Amendment to the Articles of Agreement of the IMF be ratified immediately, thus allowing the cumulative SDR allocations to double to SDR US\$ 42.87 billion. This one-time, special allocation of SDRs should be followed by an agreement by high-income countries to allot their future receipts of SDR to programmes aimed at financing the provision of global public goods. An independent board of eminent persons, appointed on the basis of publicly-stated professional qualifications, would ensure that the needs of the recipients take precedence over the interests of donors. The SDR donations scheme would not replace existing bilateral or multilateral assistance, but would add to it.

A variant of this proposal states that it should not to be viewed as a one-time issue, but as an annual global SDR allocation to boost world liquidity and reduce the annual shortage that affects global spending. 
While there is debate on whether the creation of SDR would really boost international liquidity in the post-Bretton Woods era, which is characterized by floating exchange rate arrangements, there are strong arguments in its favor, based on efficiency gains for the world economy. SDRs offer a costless reserve asset and this is important for improving the operation of the international monetary system ${ }^{4}$.

Though international liquidity has increased rapidly over the past decade, it has been skewed in favor of a few East Asian countries and Western Europe. Countries which are not already major players in international trade continue to suffer from foreign exchange shortages. Even relatively successful trading economies have been cautious about expanding demand at the expense of foreign exchange reserves, because financial market volatility requires that they maintain unnecessarily high reserve levels.

Most countries still need to increase their reserve holdings in view of expanding current and capital account fluctuations. Attempting to accomplish this by generating a balance of payments surplus would be costly in terms of foregone consumption and investment. On the other hand attempting to borrow needed reserves on the international capital markets is very costly, and some countries have no access to such markets. Though, to some extent, borrowed reserves may substitute for owned reserves, "volatile capital flows demonstrate that undue reliance on international capital markets for (the) purpose (of holding reserves) can be risky" compared to the cost of foregoing consumption and investment, and the cost of borrowing from the capital markets.

\section{Global taxation and tax cooperation}

Taxation emerges as one of the main alternatives for generating the public resources needed to finance development and the provision of global public goods. Schemes to generate such tax revenues would no doubt have greater credibility if the revenues were assigned to some universally valued goals, such as eliminating hunger or illiteracy. This is one reason why earmarking is an essential feature of a possible global tax.

To date, research suggests that new sources could raise sums to fill the existing gap to finance development. The conclusions of Clunies-Ross (2003) are summarized in the Table 3 on page 8 .

If these estimates are broadly correct, then there appear to be several ways in which a sum could be raised equal to or exceeding existing ODA. The arms-trade tax is only a modest revenue-earner. Taking into account fiscal productivity, progressivity in terms of both nations and people and difficulties of implementation, the carbon tax and the currency transaction tax (or so-called Tobin tax) emerge clearly as more likely to open a new era of global taxation.

The imposition of a new global tax requires careful analysis. Where global taxation is concerned, countries must act in concert, and there is perhaps no other area in which the institutional arrangements under which multilateral action takes place are so important.

\footnotetext{
${ }^{4}$ See Clark and Polak (2002) for a debate on this issue.

${ }^{5}$ Clark and Polak (2002), p 11
} 
There are non-trivial coordination issues associated with an international tax, since, in the absence of a world tax authority, taxes would have to be collected by national governments but with an earmarked destination. In order to avoid leakages and evasion, the success and effectiveness of some of the schemes proposed depend on complete compliance of all countries. With a carbon tax, or with the Tobin tax, failure of countries to participate may erode the tax base as producers relocate, and expose participating countries to intense lobbying from domestic interests.

Table 3. Global taxation: alternatives, estimated revenues and some difficulties involved

\begin{tabular}{|c|c|c|}
\hline Taxes & Revenue estimates & Difficulties \\
\hline Arms-trade taxes & $\$ 5$ billion & $\begin{array}{l}\text { - Taxing the legitimate arms trade would largely } \\
\text { involve taxing governments themselves. } \\
\text { - Proportionately to income, the burden of a } \\
\text { uniform tax would quite possibly fall most heavily } \\
\text { on poorer countries, so that internationally the tax } \\
\text { might well be highly regressive in its incidence. }\end{array}$ \\
\hline $\begin{array}{l}\text { Tax on international } \\
\text { air transport }\end{array}$ & less than $\$ 20$ billion & $\begin{array}{l}\text { - The burden would bear particularly hard on } \\
\text { countries dependent on tourism, as they are often } \\
\text { poor with few alternative exploitable resources } \\
\text { and might need compensation. } \\
\text { - Given the current civil aviation crisis, it could not } \\
\text { be adopted in the near future. }\end{array}$ \\
\hline Carbon tax & $\begin{array}{l}\$ 60 \text { billion (if levied } \\
\text { on high-income } \\
\text { countries) }\end{array}$ & $\begin{array}{l}\text { Requires cooperation by governments of the } \\
\text { world in legislating and administering to be a } \\
\text { genuinely universal additional charge impinging } \\
\text { on every user of hydrocarbon fuels. }\end{array}$ \\
\hline $\begin{array}{l}\text { Tobin tax (at rate } \\
0.02 \% \text { ) }\end{array}$ & $\$ 50$ billion & $\begin{array}{l}\text { Many financial operations are trade or direct } \\
\text { investment related. A high tax rate or a tax not } \\
\text { properly designed would ultimately prevent } \\
\text { international trading, and would restrict } \\
\text { competition. } \\
\text { - Requires international cooperation, in order to } \\
\text { avoid evasion. }\end{array}$ \\
\hline
\end{tabular}

\section{Tobin Tax}

The search for a double dividend is the essential task in designing a new tax, be it national or global. Besides generating revenues as a net addition to development resources, taxation schemes should be designed to have positive allocational effects, taxing bad things and helping to reduce the demand for some global "bads".

Sometimes, the two objectives require taxes at very different levels. As pointed out by Atkinson (2003), the Tobin tax required to raise US\$ 50 billion for development would be applied at a much lower rate than that than if it were being used to stabilize exchange rates. 
A low tax rate is essential if the Tobin tax is to be successful in generating resources. As noted by Eichengreen (1998) "it would otherwise throw boulders instead of sand in the gears". This implies that the low-rate version of the currency transactions tax would not be appropriate for allocational reasons, making it a negligible deterrent to market volatility, since in times of crisis it would simply be disregarded by currency traders.

\section{Carbon Tax}

In this context, a carbon tax seems to be the more appropriate choice. It could generate a substantial amount of revenues and would definitely help to reduce environmental damage.

Environmental taxes are potentially important as policy tools in both rich and developing countries. It has often been claimed that the desire for a cleaner environment is a "luxury good" that is primarily demanded by those with high incomes. Even if this is true, developing countries may find environmental externalities, e.g., as related to agriculture, an important barrier to economic development and therefore have a strong interest in the adoption of policies to protect the environment ${ }^{6}$. As regards global externalities, all countries in the world share a common interest in preventing global warming, pollution of the oceans and a reduction of biological diversity. This could provide the basis for global environmental taxes of benefit to all.

$\mathrm{CO} 2$ emission permits offer an alternative to taxation. These permits would be tradable in such a way that poor countries would have plenty to sell in international markets, while developed countries would need to buy them.

There are difficulties associated with the creation of any of these taxes. The resources raised by a global tax would be collected within countries but would be disbursed outside those countries. In fact, the effort of harmonization and coordination among countries would be so difficult to put in place that a new global tax does not seem to be a realistic alternative at this time.

\section{Reinforcing International Tax Cooperation}

As an alternative to the creation of a new global tax, reinforcing international tax cooperation would strengthen the capacity of national tax administrations to minimize tax avoidance and evasion.

Globalization places constraints on the ability of national governments to set and raise taxes. Several countries have used tax incentives to attract companies. Tax incentives can provide an opportunity, but can also distort the benefits of FDI, reducing potential resources available for governments to address social issues. Governments need to raise the necessary revenues to finance the services and the physical and social infrastructure that will enable their countries to move out of poverty. The response of both developed and developing countries to tax incentives has been to shift the tax burden from (mobile) capital to (less mobile) labor, with clear negative impacts on employment.

There are other taxation issues with international dimensions, requiring coordination with tax authorities of other countries. These include the taxation of multinational enterprises, the impact of international tax competition and cross-border VAT and excise issues. The establishment of an international tax agency would facilitate such cooperation and might provide additional resources for global public goods.

\footnotetext{
${ }^{6}$ See Sandmo (2003) for a complete discussion of the possible role of environmental taxation for economic development.
} 
Alternatively, international dialogue could be encouraged to develop greater coherence between relevant international organizations without creating a new institution. The result would be a Global Tax Network. Parties concerned would include the IMF and World Bank, the Committee of Fiscal Affairs of the OECD, the UN Ad Hoc Group of Experts on International Cooperation in Tax Matters and the Committee of International Organizations on Tax Administration. All countries, together with regional tax organizations and regional development banks, would be welcome to participate without preconditions.

Enhancing dialogue, rather than creating a new institution, would provide greater flexibility. A Global Tax Network would be able to share information, promote common and best practices and provide a forum for dialogue. It would also facilitate the fight against tax havens, money laundering, and the financing of terrorism.

\section{Reduction of military expenditures}

Total world military spending for 2001 has been estimated at US\$ 839 billion, a figure that represents a significant proportion of world economic resources. The 15 major spenders, a list that includes some medium income developing countries, account for over threequarters of world military spending. Five countries account for over half. If the 15 major spenders agreed to reduce their military expenditure by $5 \%$, diverting the funds to development, no less than US\$ 30 billion would be available annually for the provision of global public goods, i.e., more than half of current annual ODA flows.

There is a widespread belief that military spending spurs growth, but if this is so, it is only true in rich countries. There are other ways of spending money to spur growth, and the opportunity costs of the tremendous imbalance in military expenditure in developed and developing countries bear close examination.

\section{Debt Relief}

Debt relief is an important and relatively easy way to increase net flows to the poorest nations. It involves both private and public resources, and can be implemented in tandem with some of the proposals discussed above.

In many poor countries, mostly in Africa, external debt has reached unsustainable levels. These countries urgently need debt relief. The Initiative for Heavily Indebted Poor Countries (HIPC) was launched jointly by the IMF and the World Bank in 1996 in recognition of the severity of this problem. In spite of the progress which has been made, the Initiative needs to be broadened and accelerated. The HIPC Initiative has been underfunded, and, even for countries meeting all the criteria, it may not bring about a sustainable debt burden.

According to reports from the Initiative, the majority of countries that reached the intermediate phase of the programme have not yet reached the final stage or "completion point". As of September 2003, only 8 countries had reached the completion point, leading to estimated relief in nominal debt service of US\$ 14.7 billion; by contrast, there were 19 countries that had reached their "decision points", corresponding to potential relief of US\$ 37.2 billion in nominal debt service. 
It is important to maintain the conditions currently attached to the debt relief programme, which are designed to ensure that savings on debt service are channelled into increased spending on growth-enhancing social programmes. Any debt relief programme should be accompanied by an increase in ODA from the most developed countries and all creditors, including bilateral creditors, must honor the commitments to debt cancellation which they assume under the HIPC Initiative. If not, the developing countries themselves will bear the cost of debt relief and the programme will continue to be much less effective than expected.

Countries that are dependent on commodity exports also require attention, since they can suddenly find themselves in a situation of debt unsustainability due to a reduction in commodity prices. The link between debt sustainability and the overall performance of the international economy reinforces the importance of overcoming the current trade barriers faced by developing countries.

\subsection{Private flows to developing countries}

The search for innovative sources to finance development has not been restricted to public resources. Several types of private flows can play an important role in helping developing countries. These include investment, remittances and donations.

\section{Investment}

It is especially important to create incentives for private resources to flow into development. This is because, economic swings notwithstanding, there is more money in private hands searching for investment opportunities in even the most unusual places, than there is in the hands of western governments. As flows of development assistance from governments and multilateral institutions diminish, recognition is growing that private capital can ultimately make a difference and help a range of underdeveloped countries turn the corner.

\section{Remittances}

Remittances from migrants are a growing and relatively stable, market-based external source of development finance. As stressed by Solimano (2003), "for receiving countries, remittances can become a powerful tool of development finance: they are a source of foreign exchange, a complement to national savings and a direct source of investment project finance. Remittances can have a positive poverty- reducing effect, as many families of migrants who receive remittances are low-income people. Properly mobilized remittances can contribute to increased investment in housing and human capital (education) and help finance micro and small-scale firms."

Recently, remittances have reached around US\$ 80 billion a year. They are more important than foreign aid. Currently, they are the second most important source of external finance for developing countries, after FDI (see Table 4, page 12). They are relatively concentrated in a group of developing countries: the top 20-recipient countries receive around $80 \%$ of total workers remittances. 
This provides a case for policy intervention, since it would be possible to leverage greater value for remittances if international money transfers were conducted at lower costs. The international markets for remittances are segmented and inefficient, as reflected by high costs of intermediation. The market is dominated by operators that charge high fees and use overvalued exchange rates for money transfers. Commercial banks in both source and recipient countries have a low share of the global remittances market. Therefore, the amount of remittances is below the socially optimal amount associated with a more competitive cost structure in the market. The development potential of remittances is thus diminished under current market realities and could be enhanced by greater competition.

Table 4. Remittances and other flows of resources to developing countries, 1991-2002 (Billions of US dollars)

\begin{tabular}{|l|r|c|c|c|c|c|c|c|}
\hline & Average 91-95 & $\mathbf{1 9 9 6}$ & $\mathbf{1 9 9 7}$ & $\mathbf{1 9 9 8}$ & $\mathbf{1 9 9 9}$ & $\mathbf{2 0 0 0}$ & $\mathbf{2 0 0 1}$ & $\mathbf{2 0 0 2}$ \\
\hline Remittances & 40,2 & 52,6 & 62,7 & 59,5 & 64,7 & 64,6 & 72,3 & 80 \\
\hline Official aid & 49,3 & 51,9 & 46,6 & 50,3 & 52,4 & 50,5 & 52 & NA \\
\hline $\begin{array}{l}\text { Other official } \\
\text { flows }\end{array}$ & 8,5 & $-7,8$ & 7,2 & 16,2 & 5 & -3 & & NA \\
\hline FDI & 62,9 & 128 & 169 & 175 & 179 & 161 & 172 & 143 \\
\hline $\begin{array}{l}\text { Other private } \\
\text { flows }\end{array}$ & 72,7 & 148,4 & 131,4 & 108,8 & 45,1 & 65,1 & $-11,7$ & NA \\
\hline Total & 233,6 & 372,9 & 417,2 & 409,3 & 346,6 & 338 & 284,3 & 223 \\
\hline
\end{tabular}

Source: Solimano (2003), p. 30

Both sending and receiving countries could increase competition and reduce costs in the remittances market. According to Solimano (2001 and 2003), in sending countries, a regularization of the legal status of migrants would make the migrant sector more attractive to formal financial institutions as suppliers of financial services, including remittances, for migrants. This would increase competition and reduce costs. The costs of licensing new operators and the regulatory environment should avoid imposing extra burdens on the sector.

In receiving countries, the issuance of remittance bonds, the opening of foreign currency accounts for migrant workers, and the creation of facilities for voluntary donations for projects are all measures which could leverage remittances for development. The creation of education and housing accounts for migrants could help to enhance the productive and social use of remittances proceeds. Encouraging emigrants to return home could bring fresh capital, new ideas and international contacts and be a promising way to attract remittances for growth and development. .

\section{Charity}

\section{Individual philanthropy}

Individual philanthropy should also be explored as a way of raising funds for development. Measures to encourage private funding of development through United Nations agencies, global funds, the Internet, among others, have been under discussion. 
In a purely private scheme, the increased flow of resources is critically dependent on the willingness of individuals to contribute. As shown by several studies, there is a range of motives at play in donor decision-making. ${ }^{7}$ Most of the main factors do not work in favor of development, compared to other options for charitable giving. Factors such as scale and persistence of need, empathy and relationship to recipient are considered particularly relevant ones and tend to operate in favor of making donations close to home.

Increasing private donations to development requires neutralizing the limiting factors and exploiting what few advantages development may have in attracting funds.

Miklewright and Wright (2003) point to the super-rich as a potential source of development donations, provided accountability and visibility for the donor are guaranteed. This is demonstrated by the recent experience of setting up global funds, described by Clunies-Ross (2003), including the Vaccine Fund/Global Alliance for Vaccines and Immunization (GAVI), the International Aids Vaccine Initiative (IAVI) and the Global Fund to Fight AIDS, Tuberculosis and Malaria. As their names indicate, these funds are exclusively in the health area.

\section{Tax incentives}

Tax incentives are a second way to motivate donors to contribute to development. This is actually a way of mobilizing public resources, but its optional character makes it a special case. In countries where tax incentives for charitable giving already exist, applying them to development would only require adding a line to the tax forms. Where charitable contributions are not deductible for income tax purposes, development would compete with other options for the increased philanthropy that a more favorable tax treatment could generate.

However, even if governments were to establish more favorable tax treatment of donations to development to meet the Millennium Goals, there would be significant administrative difficulties in defining a qualifying donation. In practice, this could only be achieved by defining qualification criteria for charities, such as the share of their expenditures which they direct to developing countries. This could stimulate more donations to charities which already qualify and also provide an incentive to other charities to spend money abroad so that they could meet the criteria.

Even though these mechanisms are limited in their potential to generate substantial resources, they are attractive ways of raising complementary funds for development, since they are rooted in solidarity, voluntary behavior and partnership. And, there are two advantages in working through charity and tax incentives, instead of new forms of taxation. First, implementation is easier, since the intense coordination among governments needed to create new global taxes is not required. Second, these mechanisms are more acceptable to taxpayers, who are not being subjected to a decision made by governments to tax their citizens but are making a choice of their own.

\subsection{Private capital flows to poorer countries}

Private capital flows have tended to be highly concentrated even among developing countries. This is true of both Foreign Direct Investment and other private financial flows, where a few emerging market economies dominate the scene. It is an important challenge to redirect private capital flows to least developed countries and make globalization more inclusive.

\footnotetext{
${ }^{7}$ See Miklewright and Wright (2003)
} 
Enabling conditions created by countries to attract private capital flows are crucial. These flows, especially FDI, are largely attracted by the quality of a country's institutions and by good governance. Therefore the stability and good regulation of the domestic financial system are very important.

Table 5. Countries receiving Foreign Direct Investment - Ranking and cumulative share - 2000

\begin{tabular}{|l|c|c|c|}
\hline \multicolumn{1}{|c|}{ Countries } & $\begin{array}{c}\text { FDI inflows (US } \\
\text { billions) }\end{array}$ & $\begin{array}{c}\text { Share of world } \\
\text { inflows (\%) }\end{array}$ & Cumulative share (\%) \\
\hline 1. United States & 281 & 22 & 22 \\
\hline 2. Germany & 176 & 14 & 36 \\
\hline 3. United Kingdom & 130 & 10 & 46 \\
\hline $\begin{array}{l}\text { 4. Belgium and } \\
\text { Luxembourg }\end{array}$ & 87 & 7 & 53 \\
\hline 5. Hong Kong & 64 & 5 & 63 \\
\hline 6. Canada & 63 & 5 & 67 \\
\hline 7. Netherlands & 55 & 4 & 71 \\
\hline 8. France & 44 & 3 & 74 \\
\hline 9. China & 40 & 3 & 77 \\
\hline 10. Spain & 36 & 3 & 80 \\
\hline 11. Brazil & 33 & 3 & 82 \\
\hline 12. Sweden & 21 & 2 & 83 \\
\hline 13. Ireland & 16 & 1 & 84 \\
\hline 14. Denmark & 15 & 1 & 85 \\
\hline 15. Mexico & 13 & 1 & 86 \\
\hline 16 Australia & 11 & 1 & 87 \\
\hline 17. Italy & 11 & 1 & 88 \\
\hline 18. Argentina & 11 & 1 & 88 \\
\hline 19. South Korea & 10 & 1 & 89 \\
\hline 20. Poland & 10 & 1 & \\
\hline
\end{tabular}

There are some fundamental trends and tendencies in the current international economic context that have been stressed by Crocker Snow Jr. (2003):

\section{Comparative returns from investing in developing countries}

With reduced rates of growth in every major western economy where most money is pooled, comparative opportunities for high returns in developing countries are greater than before. There is much less development money in government coffers than investment money in private hands. For governments, donor fatigue is a factor. For the private sector, opportunity beckons. The stagnancy that inhibits private finance leaders in western economies and undermines their bottom line can prompt them to experiment with developing country assets in public or private markets. With the ease of cross-border investing, the returns from certain Third World equity markets can be more attractive than investment returns in the more saturated and now stagnant western markets. 


\section{The importance of good governance}

The development of local equity markets, the rule of law and transparency - the myriad details that fall within the basket of "good governance" - are important to attracting private capital. Without these, only limited amounts of foreign capital will flow. The gradual spread of World Trade Organization standards from trade to investments lends some uniformity to the process. The influence of rating agencies such as S\&P and Moody's is sometimes exaggerated. Awareness by investors that these agencies have their own built-in distortions, relying only on economic metrics and without reflecting the informal sector, is growing. Overall on the supply side, it is the surplus of uncommitted monies available, the perception of opportunity in underdeveloped countries and the climate of socially responsible investing (SRI) that trigger money flows by major pension funds more than come-hither steps taken by countries in want.

\section{The role of domestic capital}

For the multinational investor and the fund manager who are interested in developing countries, the dynamics of domestic capital within a country is a leading indicator of whether investing in that country is a good or bad bet. Is local capital easily generated? Does this capital, intermediated or otherwise, tend to stay home and find fruitful opportunities, and if not, why not? As a leading negative indicator, is flight capital a problem, and if so is it reversible? Business persons and financiers recognize that, like charity, investment and capital creation should begin at home. They are more cautious when it doesn't.

\section{The investment climate}

In the last decade, the governments of many developing countries have burnished their investment climates to attract western finance, instituting tax havens, accountability, bankruptcy laws and the like. They expected foreign capital to respond and many have been frustrated. Competition among countries (including the U.S. and European Community countries) for limited amounts of foreign capital is an increasingly significant part of the equation. It can be compared to the intense competition among car-makers. Is the model presented better than the alternatives? Is it advertised and marketed with the right message and in the right places? Paragraph 25 of the Monterrey Consensus states, "We underscore the need to sustain sufficient and stable private financial flows to developing countries and countries with economies in transition." These are worthy words but unrealistic. Private financial flows will never be stable because investment psyches are not. The old 80:20 rule applies: more than three-quarters of all private monies flow to less than one-quarter of countries. The reason goes beyond the herd mentality of western finance; it is a function of the "hospitality factor".

\section{Portfolio fund flows}

Portfolio funds are seen by many economists as whimsical, driven by short-term thinking and with a highly volatile and, on balance, negative effect. This is in contrast to Foreign Direct Investment which is deemed to create jobs, improve local technology and working conditions and have a positive long-term effect on poor countries. However, this is not 
the whole story. Western pension and mutual fund investments overseas typically are made in government bonds or equity markets. In the growing number of developing countries with domestic stock markets, such investments are critical to their publiclyowned companies with a capacity to grow and to newly-privatized enterprises. Portfolio fund flows are a leading, if indirect, indicator of the robustness of local markets, acting as an important third leg in domestic capital formation and serving as a market-driven rating agency of Third World economies.

\section{Public-private partnerships}

Promoting partnerships between public and private sources of capital for development purposes is very much in vogue. Such real and imagined partnerships were a focus of the Financing for Development meeting, and much boosted by the UN's committee of "business interlocutors". However, examples of successful partnerships remain anecdotal. In many a public-private initiative, the goal-oriented, selfish and impatient characteristics of business are proving incompatible with the slower-paced, process-oriented patterns of government.

\section{Risk aversion}

In the dominant western economies characterized by low growth and productivity diminished by aging populations, leaders of private financial services are cutting back and tightening up. They are forced by stockholder suits and other factors to concentrate on the safe bet. Though most socially responsible investment (SRI) instruments have showed reasonable returns in the last decade, there is growing disincentive for western financial leaders to pay special attention to poor countries as a matter of "doing what's right". Their balance sheets do not encourage it and their fiduciary responsibilities will not allow it. The desire to do good must be tempered by the likelihood of doing well.

\section{SMES}

In rich and poor countries alike, genuine entrepreneurs are driven by an idea, and by the challenge of building a business and taking it to market. Typically, they are motivated more by their vision than by rates of return. Entrepreneurship is recognized as a key to western economies; roughly $60 \%$ of all jobs in the U.S. are in companies of 20 employees or less, and more than $50 \%$ of all U.S. exports come from small companies. In the jargon of development economics, the focus is on promoting "SMEs", small- and medium-sized enterprises. At the International Finance Corporation's (IFC) annual Global Private Equity Conference in May, noted American venture capitalist Alan Patrikoff focused his keynote speech on small business, pointing out that SMEs "represent well over $90 \%$ of the total enterprises (in the developing world) and more than 50-60\% of employment." The annual Global Entrepreneurship Monitor (GEM) study records a significant growth in developing world entrepreneurship, most notably in Latin America and Southeast Asia. Creating a welcoming environment for venture capital-style investments by promising people more than products is critical. Social acceptance of failure plays a part. 


\section{Information technology}

With few exceptions, the latest studies of successful development note a correlation between a developing country's investment in, and application of, communication technologies and its rate of economic growth. The more readily citizens can communicate internally and externally, the more their opportunities expand. This pattern is recognized by foreign capital institutions and helps stimulate their investment decisions. Information technologies are both a cause and an effect of western capital's developing world investment decisions. The more capital sources utilize it, the more information they have to see beyond the "low hanging fruit" and discover fresh opportunities for potential profit.

\section{Market forces}

Market forces tend to operate in spite of government policies rather than because of them. The ceaseless drive for productivity and profits leads business investors to search out the undiscovered. Their investment choices and decisions can be both random and rational. The current global environment bodes well for increased flows of private capital to the developing world. The West is saturated with consumer products; much of the developing world is not. Western countries have aging populations; the developing world does not. To many a western capitalist, the developing world represents big markets driven by population growth, with untapped natural and human resources. The opportunity speaks for itself.

Within this environment, a series of current, concrete public-private initiatives if not full partnerships hold promise of facilitating and accelerating these flows. These include:

- The Global Information Clearinghouse - one of a number of private sector initiatives tabled at the Financing for Development conference in Monterrey, this market-based web portal aims to improve investor access to the most useful and current information and analytics on developing economies;

- Emerging Market Finance Accord - an agreement forged in June 2003 by nine banks from seven countries to abide by the International Finance Corporation's newly established "Equator Principles" regarding socially responsible lending in underdeveloped countries;

- Global Horizon Fund - a projected $\$ 1$ billion global private equity fund for investments in entrepreneur-driven startup or early-stage companies in a select number of developing countries.

- Development Gateway - a comprehensive Washington-based internet portal with information on a wide range of development-related topics and issues;

- Country Investment Guides - an initiative of the Paris-based International Chamber of Commerce in cooperation with UNCTAD and support from several OECD countries; investment guides have been created for a dozen developing countries ranging from Mozambique to Bangladesh to Cambodia;

- The Wealth of Nations Triangle Index - a holistic index utilizing 63 variables culled from the best public and private sources and divided equally among economic, social environment and information exchange factors to rank and measure the balance among these factors for 70 developing countries. 


\section{Rating agencies}

Rating grades influence the viability of a prospective bond issue by influencing the cost of debt and the number of prospective investors. As a result, countries with no ratings or a rating below "investment grade" are unable to borrow from the international capital market or can do it only at a very high cost. They consequently depend on official loans from multilateral organizations like the World Bank and various development banks, or loans from friendly governments. Rating agencies emphasize economic rather than sociopolitical indicators. Including additional variables would provide investors with a better picture of a country's economic viability. The idea is to broaden the definition of a healthy market, including implicit long-run considerations.

These additional variables, notably indicators on labor market conditions and social stability, can also provide incentives to national governments to develop their social and labor standards in order to attract investment and can promote a longer-term investment perspective.

\section{Local capital markets}

Another mechanism for increasing investments ratios is for financial multilateral agencies to speed development by borrowing in local capital markets for long-term projects. There are several developing countries where saving rates are high, but lack of competent or trusted borrowers means that capital does not flow to long-term projects. The World Bank and Asian Development Bank are experimenting with this.

\section{Reform of the financial architecture}

\subsection{Financial crises}

Over the past 10 years, increased global capital mobility has been accompanied by a rise in the frequency of financial crises in developing countries. Disregarding a number of more limited currency and bank crises, starting in the mid 1990s the following major crises occurred: the Mexican crisis of 1994-95, the East Asia crisis, which began in 1997 and affected six countries in the region, the Russian crisis of 1998, the Brazilian crisis of 199899, the Argentinean crisis of 2001-2002, and its contagion to Uruguay and Brazil in 2002.

Financial market volatility has been a significant problem, particularly for middle income countries. Some lessons have been learned from the Asian crisis, particularly the need to phase in capital account liberalization over time (and the recognition that it may not be advisable in many circumstances) and the importance of sound domestic banking regulation for currency stability. However, as the contagion effect of the Argentinean crisis on the country's neighbors showed in 2002, much remains to be done to improve the international financial architecture and ensure that capital movement is a positive force for growth, rather than a source of disruption. 
One of the main lessons which can be drawn from the Latin American experience is that financial liberalization must go hand-in-hand with trade liberalization and increased trade integration, both of which are insufficient in most Latin American countries. Otherwise a country will not generate enough resources (exports) to service its debt, which is usually in foreign currency.

Although reversals of capital flows are often associated with a deterioration in macroeconomic conditions, they are compounded by herd-like behavior. In many cases, even countries which adopt economic policies which are generally accepted to be sound have been hit by contagion.

Financial instability affects both developed and developing countries, but the latter suffer disproportionately. This is because developing countries are often more vulnerable due to higher levels of external indebtedness and higher shares of external debt denominated in foreign currencies.

\subsection{The effects of financial crises on employment}

In the developing world, the cost of this excessive volatility has been very high. A reversal of external capital flows and a sharp decline in the currency leads to domestic instability, requiring a tightening of both monetary and fiscal policies in order to avoid inflationary pressures and debt default. This in turn leads to a loss in output and negative effects on employment. Be it through higher inflation rates or through contractionist policies and their impact on production and employment, workers and especially poorer workers tend to suffer the most.

If employment is taken as a paramount objective of our societies, there is an urgent need for action. Global economic security demands measures to limit the volatility and contagion of financial markets.

A well regulated and stable financial system could provide incentives for productive investment with maximum employment impact, while preventing the devastating employment effects of a financial crisis. But this requires policy coordination with other institutions.

There is another argument for international coordination in this area. Self-insurance is a costly option for countries in the international finance arena. Although the prevention of excessive risks at the national level is an essential element, the basic architecture of the international financial system has to be designed to reduce the costs involved in relying exclusively on national policies. The international financial architecture should aim to encourage a predictable and reliable role for foreign capital as a complement to domestic savings.

\subsection{Preventing financial crises}

Following the Mexican crisis of 1994 and the Asian crisis of 1997, a programme for the reform of the international financial structure was put in place. So far, reform has focused mainly on reducing the risk of future crises. Some measures are still being tested, but the following are seen as the basis for redesigning the international financial architecture: 
- The development of an early warning system, based on strengthened IMF surveillance and the disclosure of more information to markets. This led to the creation, of the International Capital Markets department at the IMF and the development, dissemination and adoption of standards and codes in several areas.

- The creation of credit lines with quicker access and in amounts sufficient to manage shocks effectively. Two new IMF facilities were created: the Supplemental Reserve Facility (SRF), aimed at providing large-scale assistance to a country with a "sudden and disruptive loss of market confidence reflected in pressure in the capital account"; and the Contingent Credit Lines (CCL), designed to help countries cope with contagion.

- The improvement of international supervision by the Bank for International Settlements and the IMF, in order to strengthen financial sectors, including tax havens. As part of this effort the Financial Sector Assessment Programme (FSAP), operated jointly by the IMF and the World Bank, has significantly increased in depth and coverage. The main objective of the FSAP is to help developing countries enhance their resilience to adverse developments, including cross-border contagion.

These three groups of initiatives deal with the prevention of crises. They are based on the well established view that imperfect information plays a central role in market failures in the financial sector. Providing better information is the essential element in ensuring better market performance. Strong evidence that contagion was a common feature of the crises of the 1990s was behind the consensus on the need to increase the supply of emergency financing in times of crisis.

These initiatives are useful, but their impact will probably be gradual, since adherence to new norms and standards by both official institutions and private companies requires considerable periods of time. The difficulties and costs associated with the rapid implementation of these codes in the developing world, especially in the poorest countries, must be recognized. There is also concern that developing countries are not being adequately involved in the design of these standards and that the measures should also include developed countries.

There are other initiatives for crisis prevention which should be adopted. Multilateral financial institutions could accelerate studies to ease the currency mismatches which are considered by many to be one of the major difficulties faced by most developing countries. A large group of countries, representing an overwhelming majority of the population and GDP of the developing world, has no alternative but to borrow in hard currency which becomes increasingly expensive to repay as the national currency suffers devaluation during financial crises caused by contagion or instability. ${ }^{8}$

One could argue that this kind of problem is simply a symptom of inadequate policy credibility, reflecting weaknesses in the domestic policies of developing countries. But, as shown by Eichengreen, Hausmann and Panizza (2002), the mismatch in the balance

\footnotetext{
${ }^{8}$ Some authors call the fact that most countries can not borrow abroad in their own currencies the "original sin". See Eichengreen, Hausmann and Panizza (2002) for a in-depth analysis of the problem
} 
sheets of many countries is not easily explained by variables like monetary credibility, fiscal solvency and contract enforcement. These authors find that "explanations based on factors limiting the incentives for currency diversification by global investors", mainly transaction costs, provide a better explanation. There is therefore a case for an international solution to the problem which would overcome the obstacles created by the structure and operation of financial markets.

As suggested by Eichengreen, Hausmann and Panizza, the possibility of new bond issues based on a basket of developing country currencies should be examined. As an alternative, the creation of an insurance fund against currency risk could encourage lenders to provide money for local investment in developing countries.

Regarding national policies, countries should adopt prudence and appropriate sequencing in the pace of capital account liberalization. Free access to foreign finance, particularly short-term finance, has proved to be incompatible with financial stability in an environment where the state's capacity to regulate is limited and where there are severe, yet hidden, balance sheet problems with banks and private corporations. In this context, countries should consider the regulation of capital inflows during booms to limit shortterm foreign borrowing by all domestic entities. The experiences of Chile and Colombia in the first half of the 1990s and of some Asian countries like Taiwan, suggests that these regulations can be helpful as crisis-prevention measures. As mentioned in the Zedillo Report, there "may be occasions during capital surges when the introduction of temporary capital inflow taxes proves to be part of the least-bad policy mix."

\subsection{Managing financial crises}

There will still be crises, no matter how much the quality and flow of information are improved. The instability of the system reflects information problems that are largely unsolvable. Therefore, it is essential to take actions to improve crisis management.

\section{Orderly debt workout procedures}

As recently argued by the IMF, orderly debt workout procedures are a key element in managing crises. These procedures must recognize the special nature of bankruptcies resulting from external shocks and the collective action problems in organizing a dialogue between sovereign debtors and a very large number of creditors. An international bankruptcy mechanism that expedites restructuring and guarantees an adequate sharing of the burden of adjustment would greatly contribute to reducing the employment impact and the social costs of financial crises and would provide a basis for stronger growth.

\section{Sovereign Debt Restructuring Mechanism (SDRM)}

Attention has been directed to the creation of a Sovereign Debt Restructuring Mechanism, or SDRM. The objective of an SDRM is to facilitate the orderly, predictable, and rapid restructuring of a sovereign's debt in those circumstances where the IMF member's debt is judged to be unsustainable. If properly designed and implemented, this mechanism would increase the efficiency of international capital markets and result in better global allocation of capital. Another approach, called a "contractual approach", relies on a more ambitious use of the collective action clauses (CAC) found in some sovereign bond contracts. So far, only issues under European law

\footnotetext{
${ }^{9}$ See UN (2001) See also Eichengreen (1999).
} 
have included CAC, while issues under New York law have not, reflecting a resistance by U.S. financial markets to these clauses. There have been some exceptions recently in Latin America, such as Mexico and Brazil.

There has been some strong opposition to the SDRM by market operators, the U.S. administration and a number of middle-income countries, especially in Latin America, particularly those who depend on financial flows, for fear that their access to international financial markets would be impaired. The other criticism of the SDRM is that it does not provide an adequate framework to prevent or resolve the external financial crisis since it applies only to sovereign debt issued under external jurisdictions. Looking back at the eight serious recent external financial crises, only in one case, that of Argentina, was externally-issued sovereign debt the highest proportion of debt involved. The other cases involved sovereign debt issued under domestic law or external debt of the private sector, which are not covered by the mechanism as now envisaged.

So far, the responses to crises have been broadly unsatisfactory. Bailing out governments and investors with rescue packages is expensive and gives the wrong incentives for both lenders and borrowers, setting the stage for further crises. Letting countries devalue and suspend debt payments can have devastating impacts on their economies, their neighbors and global financial markets, as demonstrated by Russia in 1998 and Argentina in 2002. In this context, moving towards the creation of a more orderly way of restructuring debts seems to be the most appropriate and viable alternative to large scale bailouts and devastating defaults.

Another important component of the crisis management structure is the new approach to programme financing by the IMF, which relies on a more balanced mix of adjustment and financing and avoids excessive bailouts that mostly favor creditors.

Finally, increasing the supply of emergency financing in times of crisis should be considered as a mechanism to help developing countries solve their financial crises. So far, the mechanism currently adopted by the IMF seems limited in scope and in the amount of resources available.

\subsection{Institutions}

The improvement of macroeconomic coordination at the global level can play a major role in reducing the volatility of the international financial system. There is a need for mechanisms that would facilitate consultation and surveillance of national macroeconomic policies. This includes the more obvious need for expansionary policies in industrialized countries during international financial crises, as well as exchange rate coordination among the three major reserve currencies (the dollar, the euro and the yen). It could also involve collective lines of defence for developing countries when faced with cycles of risk aversion.

The increasingly global character of financial markets suggests that there can be significant potential benefits from a move towards a new institutional framework in which financial markets operate. National policies would still be the basis for supervision and regulation, but they should be combined with international coordination. There is broad agreement on the need for prudent regulation and improved supervision. The creation of a network of institutions, like a Financial Stability Forum, consisting of representatives from the finance ministries of a number of countries and multilateral organizations, can be an important step towards coordination and enhanced regulation in international financial markets. 
4. Conclusions

There are two main challenges that must be faced regarding the international financial system. First, it is necessary to find additional ways to generate resources to finance development. Second, the permanence of excess volatility and recurrent crises reinforces the need for strengthening the architecture of the international financial system. These two challenges are intertwined, but their resolution may require independent actions.

Estimates for the additional cost of achieving the Millennium Development Goals (MDGs) are currently in the range of US $\$ 50$ billion to US\$ 100 billion a year. Despite the commitment that world leaders made at the 2002 Monterrey Conference to forge a new partnership between developed and developing countries, Official Development Assistance (ODA) commitments so far come to less than approximately US $\$ 20$ billion.

New public resources are needed. Realistic proposals include an International Development Trust Fund, which would provide long-term pledges of money to back bond issues, and new and regular issues of Special Drawing Rights to re-balance international liquidity. Reallocating part of military spending could also help raise funds for development.

Taxation emerges as one of the main alternatives for generating the public resources needed to finance development and the provision of global public goods. There are, however, nontrivial coordination issues associated with international taxation. Reinforcing international tax cooperation stands as an alternative mechanism that would strengthen the capacity of national tax administrations to minimize tax avoidance and evasion.

Private resources can also be very important. Charity and remittances are among private sources that can be stimulated to fund development objectives. The use of tax incentives to encourage donations for development (a special way of mobilizing public resources) should also be considered. Though this mechanism has limited potential for generating resources, it is rooted in solidarity and voluntary behavior and hence is an attractive way to raise complementary funds for development.

Private capital is essential. There is much more money in private hands searching for opportunities than in the hands of western governments. Mobilizing domestic resources by increasing savings, reducing capital flight and ensuring efficient intermediation are all necessary. These measures require stable currencies, predictable policies and a reliable legal framework to retain national capital and stimulate its return. The confidence of domestic capital within a country is seen as a leading indicator of whether that country is a good or bad place to invest and may partly explain why private flows are concentrated in a small number of countries.

Regarding the international financial architecture, in spite of some recent progress towards reducing the risk of financial crises, reforms are still required. Further initiatives for crisis prevention should be adopted. Multilateral financial institutions could accelerate studies to ease currency mismatches that are considered by many as one of the major difficulties faced by most developing countries. A large group of countries, representing an overwhelming majority of the population and GDP of the developing world, has no alternative but to borrow in hard currency that becomes increasingly expensive to repay as the national currency suffers devaluation during financial crises caused by contagion or instability. 
In the area of crisis management, the main issue is still the introduction of orderly debt workout procedures that recognize the special nature of bankruptcies resulting from external shocks and the collective action problems of organizing the dialogue between sovereign debtors and a large number of creditors. The importance of this discussion is clear, given the fact that the responses to crises adopted so far - massive bailouts and suspension of payments - are broadly unsatisfactory. 


\section{References}

Aryeetey, E. 2003. "A Development-focused Allocation of the Special Drawing Rights", paper prepared for the WIDER project on Innovative Sources for Development Finance.

Atkinson, A.B. 2003. "Innovative Sources of Development Finance: Global Public Economics", paper prepared for ABCDE World Bank Conference on Development Economics-Europe, Paris.

Avi-Yonah, R. 2003. "Globalization and Tax Competition: Implications for Developing Countries", paper prepared for the WIDER project on Innovative Sources for Development Finance.

Clark, P.B. and J.J. Polak. 2002. "International Liquidity and the Role of the SDR in the International Monetary System", IMF Working Paper WP/02/217, Washington D.C.

Clunies-Ross, Anthony. 2003. "Resources for Social Development", paper prepared for the World Commission on the Social Dimensions of Globalization.

Crocker Snow Jr. 2003. Truth and Consequences of Private Capital Flows.

Eichengreen, B. 1999. Toward a New International Financial Architecture. Institute for International Economics, Washington.

Eichengreen, B., Hausmann, R. and Panizza, U. 2002. "Original Sin: The Pain, the Mystery, and the Road to Redemption", paper prepared for the Inter-American Development Bank.

Grabel, I and Nissanke, M. 2003. "The Taxation of Currency and Short-Term Capital Flows", paper prepared for the WIDER project on Innovative Sources for Development Finance.

Griffith-Jones, S. and J.A. Ocampo. 2000. "Facing the Volatility and Concentration of Capital Flows", Reforming the International Financial System, J.J. Teunissen ed., FONDAD, The Hague.

HM Treasury. 2002., Tackling Poverty: A Global New Deal - A Modern Marshall Plan for the Developing World, London.

Mavrotas, G. 2003. "The International Finance Facility", paper on the U.K. HM Treasury - DFID Proposal to Increase External Finance to Developing Countries prepared for the WIDER project on Innovative Sources for Development Finance.

Micklewright, J and Wright, A (2003). "Private Donations for International Development", paper prepared for the WIDER project on Innovative Sources for Development Finance.

Sandmo, Agnar. 2003. "Environmental Taxation and Revenue for Development", paper prepared for the WIDER project on Innovative Sources for Development Finance.

Solimano, A. 2001. International Migration and the Global Economic Order: An Overview. World Bank Policy Research Working Paper \# 2720.

Solimano, A. 2003. "Emigrants Remittances as a Source of Development Finance", paper prepared for the WIDER project on Innovative Sources for Development Finance.

Soros, George. 2002. On Globalization. Oxford: Public Affairs, Ltd.

United Nations. 2001. Report of the High-Level Panel on Financing for Development (chair Ernesto Zedillo). New York: United Nations. 
United Nations. 2002. Financing for Development. New York: United Nations.

UNDP 2003 Human Development Report. New York: United Nations. 


\section{Policy Integration Department Working Papers prepared for the World Commission on the Social Dimension of Globalization}

No. 16 International finance: Meeting the needs of people in developing countries, José Guilherme Almeida dos Reis

No. 17 The gender dimensions of globalisation of production, Stephanie Barrientos, Naila Kabeer and Naomi Hossain

No. 18 Social exclusion in the context of globalization, Jan Breman

No. 19 Gender and globalization: A macroeconomic perspective, Çağatay Nilüfer and Ertük Korkurt

No. 20 Globalization, social exclusion, and work: With special reference to informal employment and gender, Marilyn Carr and Martha Chen

No. 21 Resources for social development, Antony Clunies Ross

No. 22 Does the new international trade regime leave room for industrialization policies in the middle-income countries?, Alisa DiCaprio and Alice Amsden

No. 23 Social dimension of globalisation in Latin America: Lessons from Bolivia and Chile, Alvaro García Hurtado

No. 24 Globalization: Social impact and policy actions: A partly annotated bibliography, Bernhard Gunter and Rolph van der Hoeven

No. 25 The social dimension of global production systems, Susan Hayter

No. 26 Reforming global economic and social governance:

a critical review of recent programmatic thinking, Jeremy Heimans

No. 27 Corporate social responsibility: An issues paper, Michael Hopkins

No. 28 Upgrading in global value chains, John Humphrey

No. 29 Implications of globalization and economic restructuring for skills development in Sub-Sahara Africa, Richard K. Johanson

No. 30 The outcome and impact of the main international commissions on development issues, Frédéric Lapeyre

No. 31 Globalization and structural adjustment as a development tool, Frédéric Lapeyre

No. 32 Globalization and perceptions of social inequality, Malte Luebker

No. 33 The changing structure of trade linked to global production systems: what are the policy implications?, William Milberg

No. 34 Corporate social responsibility: An overview of principles and practice, Jill Murray

No. 35 Inclusive development strategy in an era of globalization, Ignacy Sachs

No. 36 Social consequences of the globalization of the media and communications sector:

Some strategic considerations, Seán Ó. Siochrú

No. 37 Globalization, history and international migration - A view from Latin America, Andrés Solimano

No. 38 Towards a different kind of globalization, or how the anti-globalizers view the world, Gijsbert van Liemt 